\title{
DAPSONE HYPERSENSITIVITY SYNDROME: A COMPLICATION OF DAPSONE THERAPY
}

\author{
LAKSHMI NARASIMHA GUNTURU ${ }^{1 *}$, SUNAINA V ${ }^{1}$, REDDY SANTHOSH ${ }^{1}$, HARI KIRAN VN ${ }^{2}$
}

${ }^{1}$ Department of Pharmacy Practice, Annamacharya College of Pharmacy, Rajampeta, Andhra Pradesh, India. ${ }^{2}$ Department of Pharmacy Practice, Government General Hospital, Anantapuram, Andhra Pradesh, India. Email: gunturunarasimha007@gmail.com

Received: 31 January 2021, Revised and Accepted: 21 February 2021

ABSTRACT

Dapsone is chemically sulfonamide with its leprostatic mechanism used in the treatment of Hansen's disease. It is one of the safest drugs in leprosy patients. Apart from its safety, it is associated with various adverse effects such as hemolytic anemia, allergic dermatitis, agranulocytosis, methaemoglobinemia, and dapsone hypersensitivity syndrome (DHS). DHS typically presents with fever, skin eruptions, Jaundice, and hepatomegaly (organ involvement). We present a case of 35-year-old female attended to Government General Hospital with complaints of fever, skin rashes, and yellowish discoloration of the eyes. She had past medication history of dapsone taken for paucibacillary leprosy for 4 weeks. Her symptoms appeared after a month and become intolerable to dapsone. Laboratory investigations revealed hepatomegaly, anemic with jaundice. Based on dermatological examination, her diagnosis was confirmed as DHS. The drug was stopped and the patient was treated with drugs for the symptomatic cure. She was recovered from her condition and the multibacillary leprosy multidrug treatment regimen was continued without dapsone.

Keywords: Hansen's disease, Dapsone hypersensitivity syndrome, Skin eruptions, Hepatomegaly.

(C) 2021 The Authors. Published by Innovare Academic Sciences Pvt Ltd. This is an open access article under the CC BY license (http://creativecommons. org/licenses/by/4.0/) DOI: http://dx.doi.org/10.22159/ijms.2021v9i2.41008. Journal homepage: https://innovareacademics.in/journals/index.php/ijms

\section{INTRODUCTION}

Dapsone (4,4- diamino- diphenyl sulphone) is used in the treatment of hypersensitivity disorders, variety of infections. It is most widely used as an anti-leprosy drug in the treatment of Hansen's disease [1] Common side effects associated with the dapsone include hemolytic anemia, methemoglobinemia, nausea, and Jaundice, whereas severe lifethreatening adverse effects include dapsone hypersensitivity syndrome (DHS) or sulfone syndrome and Toxic Epidermal Necrolysis. DHS is a hypersensitivity reaction that occurs due to Dapsone intolerance and was first reported in 1950 by Lowe and named by Allday and Barnes [2]. It was associated with fever, skin eruptions, and hemolytic anemia that progress to jaundice with systemic organ involvement like the liver. The present case report emphasizes the 35-year-old female with DHS who was on the multibacillary leprosy multidrug treatment (MB-MDT) regimen.

\section{CASE REPORT}

A 35-year-old female patient who was on an adult MB-MDT regimen for 4 weeks presented to Government General Hospital, Kadapa with complaints of yellowish discoloration of the eyes, generalized swelling all over the body with loss of appetite. Her medical history signifies that she is a known case of Hansen's disease and has used dapsone $100 \mathrm{mg}$ daily as a part of the treatment regimen for 4 weeks. During her admission after clear examination, it was found that lesions are multiple popular lesions on the face with icterus in the eyes. Her laboratory investigations were normal except for $\mathrm{Hb}-6 \mathrm{~g} \%$, direct bilirubin - $0.7 \mathrm{mg} / \mathrm{dl}$, total protein $-5.5 \mathrm{mg} / \mathrm{dl}$, and blood urea - $41 \mathrm{mg} / \mathrm{dl}$. The condition was diagnosed as dapsone syndrome with Jaundice and the offending drug was dapsone.

\section{OUTCOME AND FOLLOW-UP}

After suspecting the condition, the patient was advised to stop dapsone and started treatment to DHS. She was prescribed with ceftriaxone injection $1 \mathrm{~g}$ OD, IV fluids, injection pantoprazole $40 \mathrm{mg}$ OD, tablet doxycycline $100 \mathrm{mg}$ OD, acetaminophen tablet $500 \mathrm{mg}$ TID, and glycerine lotion, ursodeoxycholic acid $300 \mathrm{mg}$ BD. After 8 days of treatment, the patient showed significant improvement in her condition and got discharged with medications T. Amoxicillin $500 \mathrm{mg}$ BD, T. Ursodeoxycholic acid 300 mg BD, T. Ondansetron 8 mg BD, and T. Acetaminophen 500 mg BD.

\section{DISCUSSION}

Dapsone was used in the treatment of leprosy since 1947 and considered as safest drug in anti-leprosy drug regimen, but whereas the first report of hypersensitivity to dapsone was first published in 1949 [3]. The anti-inflammatory effects of dapsone were mainly due to the inhibition of neutrophil recruitment as well as the formation of oxidants which not only kill the bacteria but also damages the tissues. It starts with a triad of symptoms such as fever, skin eruption, and internal organ involvement [4]. This was very similar to our presentation, where the patient also had a triad of signs. The other possible mechanisms which cause DHS were altered hepatic metabolism including the acetylation and hydroxylation with toxic metabolite $\mathrm{N}$ - Hydroxylamine production through N-Hydroxylation pathway is thought to be responsible for Dapsone syndrome with hemolytic anemia [5]. Here, the patient also had deceased hemoglobin levels which are due to the hemolysis of red blood cells. Evidence suggests that hepatic involvement is observed more in form of hepatomegaly, cholangitis, and liver failure. HLA-B* 13:01 single nucleotide polymorphism is a possible predictor of DHS among leprosy patients [6]. As the patient is presented with hepatomegaly and increased direct bilirubin levels (Fig. 1. Eyes of patient revealing yellowish color) which were the possible predictors for the occurrence of Jaundice, as it was one of the classical signs of DHS syndrome. In contrast to the safety of Dapsone in the MB-MDT regimen apart from DHS, it was highly associated with other severe fatal adverse effects such as agranulocytosis, toxic epidermal necrolysis, and bone marrow suppression particularly in leprosy patients [7]. Our patient responded well with the symptomatic treatment and got discharged after 8 days.

\section{CONCLUSION}

This case reported the rare and fatal adverse event of dapsone therapy and a careful vision is needed on the patients who are on the dapsone treatment. This work also signifies the managing of adverse drug reactions in MB-MDT for the successful establishment of an antileprosy regimen. Early withdrawal of the causative agent is essential to prevent the progression of the reaction. Hence, awareness should be created among the people using the MB-MDT regarding their use and side effects of drugs which would also be helpful as a part of the pharmacovigilance program. 


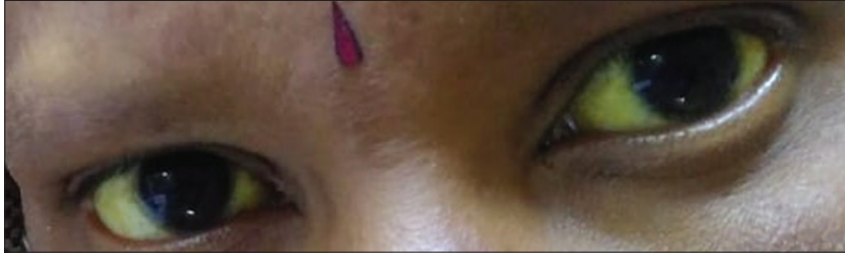

Fig. 1: Eyes of patient revealing yellowish color

\section{ACKNOWLEDGMENT}

None.

\section{CONFLICTS OF INTEREST}

Nil.

\section{FUNDING}

None.

\section{REFERENCES}

1. Vinod KV, Arun K, Dutta TK. Dapsone hypersensitivity syndrome A rare life threatening complication of dapsone therapy. J Pharmacol Pharmacother 2013;4:158-60.

2. Grace M. An unusual case of dapsone syndrome. Indian Dermatol Online J 2011;2:88-90.

3. Swetha S, Vyshnavi P, Geethanjali K, Nedamanuru K. A Case Report on Dapsone Syndrome in Leprosy Patient, EC Pulmonology and Respiratory Medicine; 2018. p. 522-4.

4. Lakshmi R, Liniya S, Vijayalakshmi S. Dapsone induced hypersensitivity syndrome-a case report. Int J Pharm Pharm Sci 2015;7:585-7.

5. Kesari HV, Gawali UP, Agharia MA. Dapsone hypersensitivity syndrome: A potentially fatal condition-case report. J Clin Diagn Res 2017;11:1-3.

6. Sinha P, Das P, Sharma N, Bhattacharjee S. A case of Hansen's disease presenting with sulfone syndrome and hemolytic anemia. J Mar Med Soc 2018;20:67-9.

7. Guragain S, Upadhayay N, Bhattarai BM. Adverse reactions in leprosy patients who underwent dapsone multidrug therapy: A retrospective study. Clin Pharmacol 2017;9:73-8. 